\title{
Resveratrol Reduces the Proinflammatory Effects and Lipopolysaccharide- Induced Expression of HMGB1 and TLR4 in RAW264.7 Cells
}

\author{
Ying Yang ${ }^{a}$ Shuping Lia Qiao Yang ${ }^{b}$ Yu Shi ${ }^{a}$ Min Zheng ${ }^{a}$ Yanning Liu ${ }^{a}$

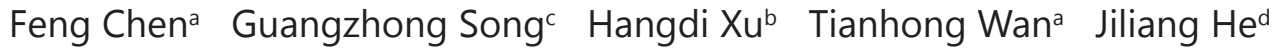 \\ Zhi Chen ${ }^{a}$
}

aState Key Laboratory for Diagnosis and Treatment of Infectious Diseases, The First Affiliated Hospital, School of Medicine, Zhejiang University, Collaborative Innovation Center for Diagnosis and Treatment of Infectious Diseases, bDepartment of Infectious Diseases, Sir Run Run Shaw Hospital, School of Medicine, Zhejiang University, 'Department of Etiology, Zhejiang Academy of Medical Sciences, dDepartment of Environmental Medicine, School of Public Health, Zhejiang University, Hangzhou, China

\section{Key Words}

Resveratrol - Lipopolysaccharides - Macrophages - High mobility group box 1 - Toll-like receptor-4

\begin{abstract}
Background: Resveratrol (Res) is a polyphenol anti-inflammatory agent. We have studied the link between the anti-inflammatory effects of Res and the high mobility group box 1(HMGB1) signaling pathway. Methods: Murine macrophage-like RAW264.7 cells (RAW264.7 cells) were either untreated (control) or treated with Res, LPS, or LPS + Res. Levels of IL$6, N O$, and TNF- $\alpha$ were measured by ELISA and colorimetric assays. Expression of HMGB1 was detected by qRT-PCR, western blot, and immunofluorescence assays. Protein and mRNA expression levels of TLR4 were also examined. Results: Res significantly reduced the levels of IL-6, NO, and TNF- $\alpha$ in RAW264.7 cells exposed to LPS. Expression levels of HMGB1 (mRNA and protein) and of TLR4 in the LPS + Res-treated cells were lower than in cells treated with LPS alone. Conclusions: Res can block the inflammatory effects induced by LPS in RAW264.7 cells. Down-regulation of HMGB expression may be one of the mechanisms of action of Res. Res may also influence TLR4 expression in the HMGB1-TLR4 signaling pathway.




\section{Introduction}

Macrophages are central players in inflammation and the immune response. Lipopolysaccharide (LPS) is a pathogen-associated molecular pattern (PAMP) and can induce inflammation. When macrophages are exposed to LPS, TLR4 recognizes LPS and causes cell activation, including the production of NO and proinflammatory cytokines such as TNF- $\alpha$ and IL-6 [1-5]. Production of NO is catalyzed by inducible NO synthase (iNOS), which can be induced by a range of stimuli, including cytokines (e.g., IL-6, TNF- $\alpha$ ) and microbes [6, 7]. Hence, proinflammatory cytokines and NO may serve as sensitive biomarkers for monitoring the response of cells to inflammation or to anti-inflammatory agents.

High mobility group box 1(HMGB1), a nuclear and cytosolic DNA-binding protein, is constitutively expressed in quiescent macrophage/monocytes, stored in the nucleus, actively secreted from stimulated immune cells, and passively released from injured cells [810]. Extracellular HMGB1 may play a critical role in the pathogenesis of inflammation, with or without infection. After HMGB1 is bound to TLR4, HMGB1-TLR4 signaling can activate macrophages and up-regulate the expression of cytokines [10-12]. When LPS-stimulated macrophages were treated with HMGB1 RNAi in vitro, expression of HMGB1 was inhibited, decreasing LPS-induced inflammatory responses [13].

HMGB1 and LPS produced synergistically toxic effects in endotoxemic mice [11]. Many in vitro and in vivo studies have demonstrated that certain agents (e.g., neutralizing antibodies) can inhibit HMGB1 activities and other agents (e.g., Chinese herbs, Danshen) can inhibit the release of HMGB1. Green tea (Camellia sinensis) and Danggui (Angelica sinensis) can rescue mice from lethal sepsis [14-17]. Resveratrol (Res, 3,4',5-trihydroxy-trans-stilbene), a polyphenol (Fig. 1) found in grapes and other plants, possesses anti-inflammatory effects and may influence macrophage activation [18-21]. The mechanism of its anti-inflammatory activity is unclear, but effects associated with the HMGB1 signaling pathway deserve study. In this study, we have investigated the anti-inflammatory effects of Res, using RAW264.7 cells exposed to LPS as a model system and NO, TNF- $\alpha$, and IL- 6 as indicators.

\section{Material and Methods}

\section{Cells and chemicals}

RAW264.7 cells were obtained from the American Type Culture Collection (ATCC, Rockville, MD) and pre-cultured in DMEM medium (Gibco BRI, Grand Island, NY) supplemented with 10\% fetal bovine serum (FBS). Adherent cells were gently washed with serum-free Opti-MEM I medium, then cultured in serum-free Opti-MEM I medium for $2 \mathrm{~h}$ before exposure to LPS (Escherichia coli 0111:B4; Sigma-Aldrich). Res (catalog no. B-002, >98\% HPLC purity) was obtained from Chengdu Herbpurify CO., LTD, and a stock solution (10 $\mathrm{mg} / \mathrm{ml}$ ) was prepared in DMSO.

\section{Detection of IL-6, TNF- $\alpha$ (ELISA) and NO}

RAW 264.7 cells cultured in 96-well plates were divided into control, Res $(60 \mu \mathrm{M})$, LPS $(0.125,0.25$ and $0.5 \mu \mathrm{g} / \mathrm{ml}$ ) and LPS+Res (corresponding LPS group plus $0,3.75,7.5,15,30$ and $60 \mu \mathrm{M}$ Res) groups. The exposure time was 24 h. Commercial ELISA kits (catalog no. DKW12-2720-096, Dakewe Biotech Company Limited, Beijing, China) were used to detect IL- 6 and TNF- $\alpha$ in the supernatant. The absorbance was read at $450 \mathrm{~nm}$ using a microtiterplate reader (BioRad, Hercules, CA) [22]. Levels of IL-6 and TNF- $\alpha$ were calculated with reference to a standard curves prepared with purified recombinant IL- 6 and TNF- $\alpha$. The levels of NO in supernatant were determined indirectly by measuring $\mathrm{NO}_{2}^{-}$production with a colorimetric assay on the basis of the Griess reaction [3]. $\mathrm{NO}_{2}{ }^{-}$concentrations were calculated by reference to a standard curve generated with $\mathrm{NaNO}_{2}$.

Measuring RNA expression levels of HMGB1 and TLR4 by qRT-PCR

RAW 264.7 cells cultured with DMEM in 96-well plates were divided into control, Res (30 and 60 $\mu \mathrm{M})$, LPS $(0.25 \mu \mathrm{g} / \mathrm{ml})$ and LPS+Res $(0.25 \mu \mathrm{g} / \mathrm{ml}$ LPS plus $0,7.5,15,30$ and $60 \mu \mathrm{M}$ Res $)$ groups. Total 
RNA was extracted from RAW264.7 cells by Trizol reagent (Invitrogen, Corp., Carlsbad, USA), according to the manufacturer's instructions [23, 24]. Quantitative determination of RNA was conducted using the GeneQuant pro RNA/DNA Calculator spectrophotometer (Amersham Biosciences, Freiburg, Germany). For each sample, RNA (100 ng) was reverse-transcribed using PrimeScript ${ }^{\mathrm{TM}}$ RT reagent Kit with gDNA Eraser (Code no. RR047A, Takara), according to the manufacturer's instructions. The transcript of GAPDH (control) was used as normalization for total mRNA input and to confirm efficiency of cDNA synthesis [25]. A
Fig. 1. The chemical structure of Resveratrol (Res).

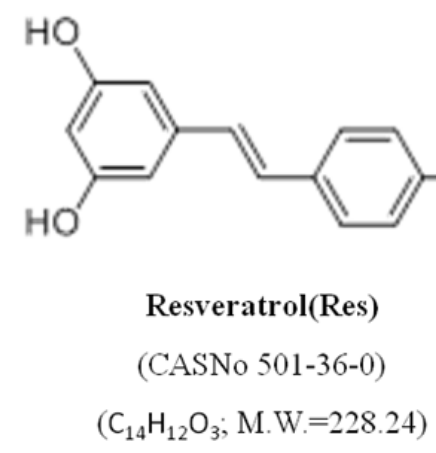

relative quantitative real-time PCR analysis was performed on aliquots of the cDNA production, using SYBR Premix EX Taq ${ }^{\text {TM }}$ II (Code. no. RR820A, Takara) in the ABI Prism 7900 (Applied Bio systems, Foster, CA, USA), according to the manufacturer's instructions. The primers were designed on the basis of published mRNA sequences of HMGB1, TLR4 and GAPDH (accession numbers: NM_010439.3, NM_021297.2 and NM_008084.2, respectively). The following primers were purchased from Sangon Biotech (Shanghai):

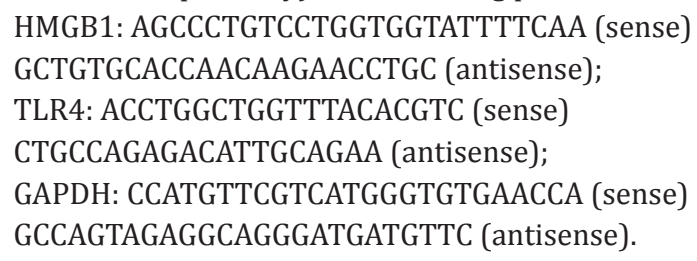

\section{Expression of HMGB1 and TLR4 proteins (western blot)}

For determination of the expression levels of HMGB1 protein in supernatant, cells were divided among control, LPS $(0.25 \mu \mathrm{g} / \mathrm{ml}$ for $24 \mathrm{~h})$, LPS+Res $(0.25 \mu \mathrm{g} / \mathrm{ml}+60 \mu \mathrm{M})$ group and Res $(60 \mu \mathrm{M})$ groups. To observe the effects of Res at different exposure times, cells were exposed to LPS for $24 \mathrm{~h}$, and exposed to Res for 0 , 6 or12 h after exposure to LPS. Cells were divided into control, LPS $(0.25 \mu \mathrm{g} / \mathrm{ml})$, Res $(60 \mu \mathrm{M})$ and three LPS+Res $(0.25 \mu \mathrm{g} / \mathrm{ml}+60 \mu \mathrm{M})$ groups.

For measurement of the ratio of cytoplasm to nuclear HMGB1 protein expression levels, cells were divided into groups, as above, and the exposure time was $24 \mathrm{~h}$.

The levels of HMGB1 in the supernatant were determined by western blot analysis as previously described [15-17,26]. Localization of HMGB1 was examined by a cell fractionation technique [27]. Cytoplasmic and nuclear extracts from cells were prepared using the Thermo Scientific NE-PER Nuclear and Cytoplasmic Extraction Reagents (Product No.78835, Thermo Scientific, Rockford, USA). The protein content of different fractions was detected by a BCA method (Product No.23225, Thermo Scientific, Rockford, USA). Equivalent amounts of protein $(20 \mu \mathrm{g})$ were separated by $12 \%$ SDS-PAGE and transferred to a polyvinylidene difluoride membrane (Millipore, Billerica, MA). The membrane was blocked in TBST containing 5\% non-fat milk and incubated with primary antibodies specific for HMGB1 (Product No. ab18256, Abcam, USA), TLR4 (Product No.ab22048, Abcam, USA), $\beta$-actin (a cytoplasmic protein marker, \#4970, Cell Signaling Technology, USA ) and proliferating cell nuclear Ag protein (a nuclear protein marker, \#2586, Cell Signaling Technology, USA ) at $4 \mathrm{C}$ overnight. After washing with TBST, the membranes were then incubated with horseradish peroxidaseconjugated anti-rabbit or mouse immunoglobulin G (Southern Biotechnology Associates, Inc., Birmingham, AL, USA) for $1 \mathrm{~h}$ at room temperature and visualized with enhanced chemiluminescence reagents (Thermo Scientific) on X-ray film. Relative band intensity was quantified using the software Quantity One v4.62 (BioRad, Inc., Berkeley, CA, USA) to determine HMGB1 and TLR4 levels [28].

\section{Detecting the HMGB1 proteins by immunofluorescence assay}

The cell treatment groups were the same as for the western blot assay; exposure time was $24 \mathrm{~h}$. Cells were plated on glass cover slips (BD Biosciences, San Jose, CA) overnight. After exposure for $24 \mathrm{~h}$, cells were washed with PBS and fixed in 4\% paraformaldehyde for $30 \mathrm{~min}$ at room temperature (RT). After fixation, cells were washed three times with PBS and permeabilized with $0.3 \%$ Triton X-100 for 15 min, then blocked 
Table 1. The levels of IL-6, NO and TNF- $\alpha$ in RAW264.7 cells exposed to LPS and Res. a: as compared with control group, $\mathrm{p}<0.01$. b: as compared with control group, $\mathrm{p}<0.05$. c: as compared with corresponding LPS group, $\mathrm{p}<0.01$. $\mathrm{d}$ : as compared with corresponding LPS group, $\mathrm{p}<0.05$

\begin{tabular}{|c|c|c|c|c|}
\hline \multicolumn{2}{|c|}{ Group } & \multirow[t]{2}{*}{ IL-6 (ng/ml, Mean \pm SD) } & \multirow[t]{2}{*}{ NO (uM, Mean \pm SD) } & \multirow[t]{2}{*}{ TNF- $\alpha(\mathrm{ng} / \mathrm{ml}, \mathrm{Mean} \pm \mathrm{SD})$} \\
\hline LPS & Res & & & \\
\hline Control & & $0.10 \pm 0.14$ & $0.39 \pm 0.23$ & $0.44 \pm 0.09$ \\
\hline 0 & $60 \mathrm{uM}$ & $0.05 \pm 0.00$ & $0.39 \pm 0.17$ & $0.50 \pm 0.05$ \\
\hline $0.125 \mathrm{ug} / \mathrm{ml}$ & 0 & $2.03 \pm 0.16^{\mathrm{a}}$ & $9.04 \pm 0.39$ a & $2.76 \pm 0.08$ a \\
\hline $0.125 \mathrm{ug} / \mathrm{ml}$ & $3.75 \mathrm{uM}$ & $0.69 \pm 0.01^{b, c}$ & $7.94 \pm 0.13 \mathrm{a}, \mathrm{d}$ & $2.36 \pm 0.08 \mathrm{a}, \mathrm{c}$ \\
\hline $0.125 \mathrm{ug} / \mathrm{ml}$ & $7.5 \mathrm{uM}$ & $0.68 \pm 0.00 \mathrm{~b}, \mathrm{c}$ & $7.65 \pm 0.26 \mathrm{a}, \mathrm{d}$ & $2.35 \pm 0.20 \mathrm{a}, \mathrm{d}$ \\
\hline $0.125 \mathrm{ug} / \mathrm{ml}$ & $15 \mathrm{uM}$ & $0.59 \pm 0.05 \mathrm{a}, \mathrm{c}$ & $6.53 \pm 0.26^{\mathrm{a}, \mathrm{c}}$ & $2.30 \pm 0.24 \mathrm{a}, \mathrm{d}$ \\
\hline $0.125 \mathrm{ug} / \mathrm{ml}$ & $30 \mathrm{uM}$ & $0.42 \pm 0.04 \mathrm{~b}, \mathrm{c}$ & $5.41 \pm 0.00 \mathrm{a}, \mathrm{c}$ & $2.17 \pm 0.03 \mathrm{a}, \mathrm{c}$ \\
\hline $0.125 \mathrm{ug} / \mathrm{ml}$ & $60 \mathrm{uM}$ & $0.40 \pm 0.22^{c}$ & $3.92 \pm 0.00 \mathrm{a}, \mathrm{c}$ & $1.66 \pm 0.07 \mathrm{a}, \mathrm{c}$ \\
\hline $0.25 \mathrm{ug} / \mathrm{ml}$ & 0 & $2.46 \pm 0.49^{a}$ & $11.37 \pm 0.44^{\mathrm{a}}$ & $4.14 \pm 0.43 \mathrm{a}$ \\
\hline $0.25 \mathrm{ug} / \mathrm{ml}$ & $3.75 \mathrm{uM}$ & $0.87 \pm 0.08 \mathrm{a}, \mathrm{c}$ & $8.22 \pm 0.00 \mathrm{a}, \mathrm{c}$ & $2.96 \pm 0.28 \mathrm{ad}$ \\
\hline $0.25 \mathrm{ug} / \mathrm{ml}$ & $7.5 \mathrm{uM}$ & $0.83 \pm 0.03 \mathrm{a}, \mathrm{c}$ & $7.94 \pm 0.13 \mathrm{a}, \mathrm{c}$ & $2.76 \pm 0.02 \mathrm{a}, \mathrm{c}$ \\
\hline $0.25 \mathrm{ug} / \mathrm{ml}$ & $15 \mathrm{uM}$ & $0.73 \pm 0.07 \mathrm{a}, \mathrm{c}$ & $6.72 \pm 0.26 \mathrm{a}, \mathrm{c}$ & $2.73 \pm 0.05 \mathrm{a}, \mathrm{c}$ \\
\hline $0.25 \mathrm{ug} / \mathrm{ml}$ & $30 \mathrm{uM}$ & $0.53 \pm 0.02 \mathrm{~b}, \mathrm{c}$ & $6.58 \pm 0.23 \mathrm{a}, \mathrm{c}$ & $2.33 \pm 0.00 \mathrm{a}, \mathrm{c}$ \\
\hline $0.25 \mathrm{ug} / \mathrm{ml}$ & $60 \mathrm{uM}$ & $0.52 \pm 0.31^{\mathrm{c}}$ & $4.48 \pm 0.00 \mathrm{a}, \mathrm{c}$ & $1.65 \pm 0.01 \mathrm{a}, \mathrm{c}$ \\
\hline $0.5 \mathrm{ug} / \mathrm{ml}$ & 0 & $24.87 \pm 3.86^{a}$ & $13.04 \pm 1.64^{\mathrm{a}}$ & $7.57 \pm 1.11^{a}$ \\
\hline $0.5 \mathrm{ug} / \mathrm{ml}$ & $3.75 \mathrm{uM}$ & $17.30 \pm 0.30 \mathrm{a}$ & $10.03 \pm 1.86^{a}$ & $6.67 \pm 2.12^{\mathrm{a}}$ \\
\hline $0.5 \mathrm{ug} / \mathrm{ml}$ & $7.5 \mathrm{uM}$ & $15.85 \pm 2.92 \mathrm{b,d}$ & $9.48 \pm 4.47^{b}$ & $5.95 \pm 0.46^{a}$ \\
\hline $0.5 \mathrm{ug} / \mathrm{ml}$ & $15 \mathrm{uM}$ & $9.91 \pm 1.07 \mathrm{a}, \mathrm{c}$ & $8.70 \pm 3.70 \mathrm{~b}$ & $5.60 \pm 0.90 \mathrm{a}$ \\
\hline $0.5 \mathrm{ug} / \mathrm{ml}$ & $30 \mathrm{uM}$ & $6.75 \pm 0.33^{\mathrm{a}, \mathrm{d}}$ & $8.12 \pm 1.22^{\mathrm{a}, \mathrm{d}}$ & $4.90 \pm 0.87 \mathrm{~b}, \mathrm{~d}$ \\
\hline $0.5 \mathrm{ug} / \mathrm{ml}$ & $60 \mathrm{uM}$ & $3.41 \pm 0.47^{\mathrm{a}, \mathrm{d}}$ & $5.10 \pm 0.08^{\mathrm{a}, \mathrm{c}}$ & $2.82 \pm 0.21 \mathrm{a}, \mathrm{d}$ \\
\hline
\end{tabular}

with $1 \%$ BSA-PBS for $1 \mathrm{~h}$ at RT. A primary rabbit antibody specific for HMGB1 was incubated overnight at 4C. The cells were washed three times with PBS, and Alexa Fluor 488-conjugated secondary antibody (Product No, A21206, Molecular Probes, Invitrogen) was added to the cellular cultures for $1 \mathrm{~h}$ at RT. The nucleus was further stained with 7-amino-actinomycin D (7-AAD, Product No. S33025, Molecular Probes, Invitrogen) and the cells were washed three times with PBS. The cover slips were mounted on glass slides with mounting medium [29] and observed using a confocal microscope (Olympus Inc., Center Valley, PA, USA). The integrated optical density (IOD) of every imaged RAW264.7 cell was determined using the ImagePro Plus 5.0 software (Media Cybernetics, Inc., Bethesda, MD, USA).

\section{Statistical analysis}

The data were analyzed with SPSS 17.0 for Windows (SPSS Inc., Chicago, IL, USA). Statistical analysis was performed with T-test to evaluate differences between groups. Each in vitro experiment was repeated at least three times and the data were represented as mean \pm SD. $p<0.05$ was considered significant.

\section{Results}

\section{IL-6, NO and TNF- $\alpha$}

Table 1 shows that the levels of IL-6, NO and TNF- $\alpha$ induced by LPS in RAW 264.7 cell cultures increased significantly with LPS dose, as compared with untreated controls $(p<0.05$ or $p<0.01)$. Moreover, the levels of IL-6, NO and TNF- $\alpha$ in LPS+Res-treated cells were significantly lower than with LPS alone $(\mathrm{p}<0.05$ or $\mathrm{p}<0.01)$.

\section{Expression of HMGB1 $\mathrm{mRNA}$}

The expression levels of HMGB1 mRNA in exposed cells are shown in Table 2. Expression in cells exposed to LPS $(0.25 \mu \mathrm{g} / \mathrm{ml})$ was significantly higher than in unexposed cells $(p<0.01)$. Expression in LPS+Res-treated cells declined significantly with Res concentration $(p<0.05$ or $\mathrm{p}<0.01$ ).

\section{Expression of HMGB1 protein}

The results of the western blot assay are shown in Fig. 2-4. Expression of HMGB1 protein in LPS+Res-treated cells was significantly lower than with LPS alone $(\mathrm{p}<0.01)$. 
Yang et al.: Res Reduces the Expression of HMGB1 and TLR4 Induced by LPS

Table 2. The mRNA levels of HMGB1 in RAW264.7 cells exposed to LPS and Res. a: as compared with control, 30uM and 60uM Res groups, $\mathrm{p}<0.01$.b: as compared with LPS group, $\mathrm{p}<0.01$. c: as compared with LPS group, $\mathrm{p}<0.05$

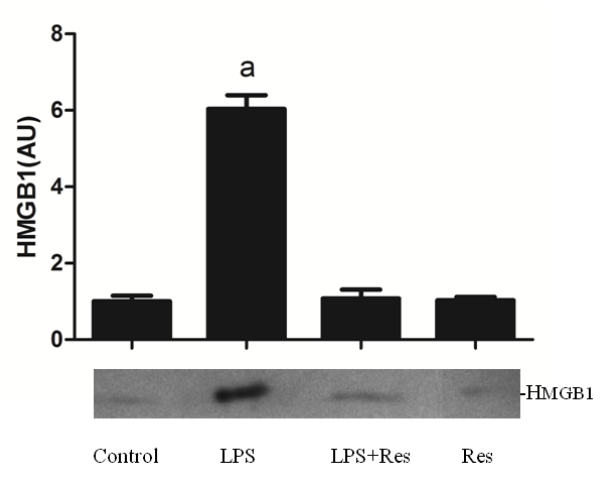

Fig. 2. The expression levels of HMGB1 protein in supernatant of RAW264.7 cell culture exposed to Res for $1 \mathrm{~h}$ then exposed to LPS for $24 \mathrm{~h}$. RAW264.7 cells were divided into four groups: control group, LPS $(0.25 \mathrm{ug} / \mathrm{ml}$ for $24 \mathrm{~h})$ group, LPS + Res $(0.25 \mathrm{ug} / \mathrm{ml}+60 \mathrm{uM})$ group and Res $(60 \mathrm{uM})$ group. A representative result of three independent experiments is shown and expressed (in arbitrary unit, $A U$ ) as the mean \pm SD of three independent experiments. a: as compared with other 3 groups, $\mathrm{p}<0.01$.

\begin{tabular}{ccc}
\hline \multicolumn{2}{c}{ Group } & mRNA levels of HMGB1 (Mean \pm SD) \\
LPS & Res & $1 \pm 0.16$ \\
\hline Control & & $0.98 \pm 0.75$ \\
0 & $60 \mathrm{uM}$ & $1.01 \pm 0.10$ \\
0 & $30 \mathrm{uM}$ & $4.80 \pm 0.47^{\mathrm{a}}$ \\
$0.25 \mathrm{ug} / \mathrm{ml}$ & 0 & $3.56 \pm 0.29 \mathrm{a}, \mathrm{c}$ \\
$0.25 \mathrm{ug} / \mathrm{ml}$ & $7.5 \mathrm{uM}$ & $2.92 \pm 0.10^{\mathrm{a}, \mathrm{b}}$ \\
$0.25 \mathrm{ug} / \mathrm{ml}$ & $15 \mathrm{uM}$ & $2.75 \pm 0.0^{\mathrm{a}, \mathrm{b}}$ \\
$0.25 \mathrm{ug} / \mathrm{ml}$ & $30 \mathrm{uM}$ & $1.31 \pm 0.28^{\mathrm{b}}$ \\
$0.25 \mathrm{ug} / \mathrm{ml}$ & $60 \mathrm{uM}$ & \\
\hline
\end{tabular}

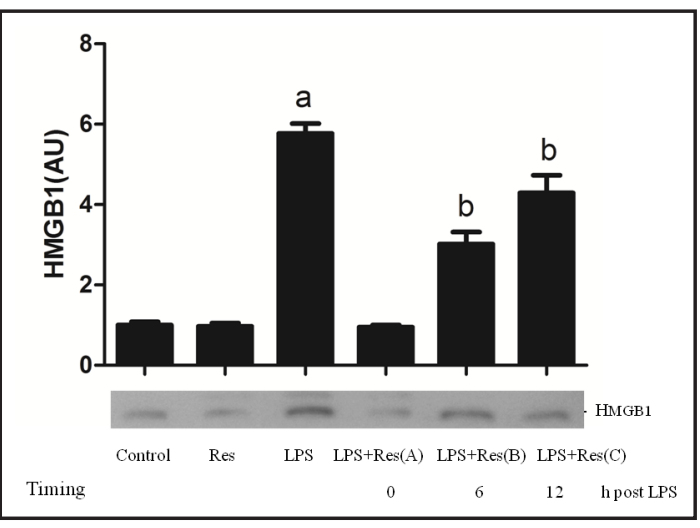

Fig. 3. The expression levels of HMGB1 protein in supernatant of RAW264.7 cell culture exposed to LPS for $24 \mathrm{~h}$, and exposed to Res after exposure to LPS for 0,6 and $12 \mathrm{~h}$. RAW264.7 cells were divided into six groups: control group, LPS $(0.25 \mathrm{ug} / \mathrm{ml})$ group, Res (60uM) group and three LPS+Res (0.25ug/ $\mathrm{ml}+60 \mathrm{uM}$ ) groups. The representative blots of three independent experiments are shown. a: as compared with other five groups, $\mathrm{p}<0.01$, b: as compared with control, Res and LPS +Res (A) groups, $\mathrm{p}<0.01$.

Fig. 3 shows the expression levels of HMGB1 protein in supernatants of cells exposed to LPS for $24 \mathrm{~h}$ and then exposed to Res for 0,6 , or $12 \mathrm{~h}$. The level in the LPS -treated cells was significantly higher than with other treatments $(\mathrm{p}<0.01)$. However, the expression levels of HMGB1 protein in two LPS+Res groups was significantly enhanced, compared with the other three (control, Res and LPS + Res A) groups $(\mathrm{p}<0.01)$.

Fig. 4 shows the ratio of cytoplasm to nuclear HMGB1 protein expression levels. This ratio, in the LPS group, was significantly higher than in control, Res, or LPS+Res-treated cells $(\mathrm{p}<0.01)$.

The result of the immunofluorescence assay is shown in Fig. 5. The ratio of cytoplasm to nuclear HMGB1 fluorescence intensity in the LPS group was significantly higher than in control, Res , or LPS+Res groups $(\mathrm{p}<0.01)$.

\section{Expression of TLR4}

Fig. 6 (A) shows the expression levels of TLR4 in four groups of cells. The expression levels of both TLR4 protein and TLR4 mRNA in the LPS group were significantly higher than in control, Res, or LPS+Res groups $(\mathrm{p}<0.01)$. 
Fig. 4. The ratio of cytoplasm to nuclear for HMGB1 protein expression levels in the RAW 264.7 cells. Cells were divided into four groups, i.e. control group, LPS group $(0.25 \mathrm{ug} / \mathrm{ml})$, LPS+Res group $(0.25 \mathrm{ug} / \mathrm{ml}+60 \mathrm{uM})$ and Res group $(60 \mathrm{uM})$. C: cytoplasm; N: nucleus; PCNA: proliferating cell nuclear antigen. The representative blots of three independent experiments are shown. a: as compared with other three groups, $\mathrm{p}<0.01$.

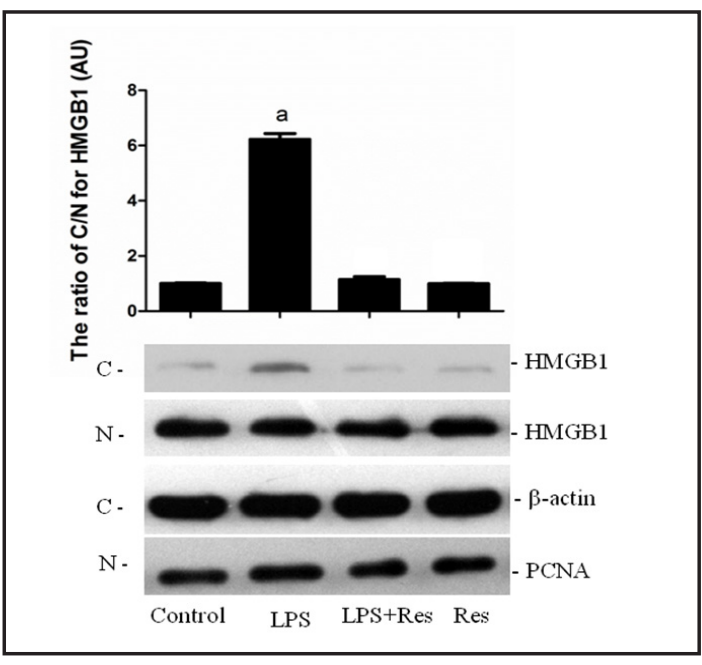

Fig. 5. The immunofluorescence for HMGB1 of RAW 264.7 cells in four groups, which were control group, LPS group $(0.25 \mathrm{ug} / \mathrm{ml})$, Res group $(60 \mathrm{uM})$ and LPS+Res group $(0.25 \mathrm{ug} / \mathrm{ml}+60 \mathrm{uM})$. (A) The ratio of cytoplasm to nuclear for HMGB1 fluorescence intensity. Numerical data represent means $\pm \operatorname{SD}(n=10)$ of three independent experiments. a: as compared with other three groups, $\mathrm{p}<0.01$. (B) The imaginings of HMGB1 fluorescence intensity. Cellular HMGB1 was immunostained with anti-HMGB1 Rabbit antibody, then stained with Alexa Fluor 488 anti-rabbit secondary antibody. The nucleus was stained with 7-amino-actinomycin D (7-AAD). Merge indicated that the combination of HMGB1 fluorescence intensity with nucleus fluorescence intensity in four groups, which demonstrated that cytoplacmic HMGB1 fluorescence intensity in LPS group significantly elevated, as compared with other three groups, $\mathrm{p}<0.01$.

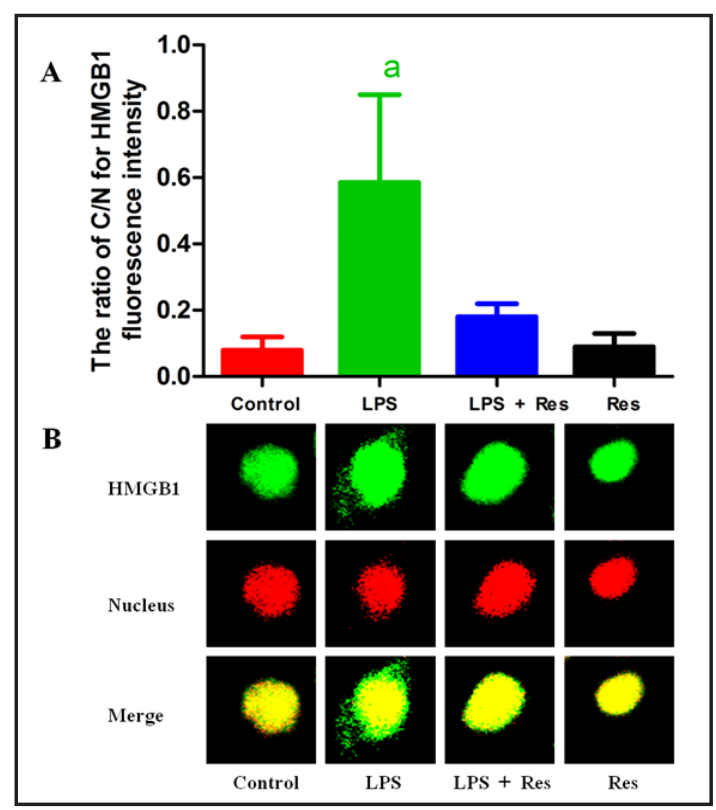

\section{Discussion}

\section{Effect of Res on LPS-induced inflammation}

Res is a polyphenolic flavonoid found in diverse plants; it is a popular nutritional supplement [30], and is of benefit in inflammatory diseases [31]. There is little evidence of significant deleterious side-effects of Res. LPS, as one of the most potent innate immuneactivating stimuli, induces enhanced cytokine and NO production in macrophages [32, 33]. The results of our study demonstrate that levels of TNF- $\alpha$, IL-6, and NO in cells exposed to LPS are significantly elevated, with a clear dose-effect relationship. Thus, RAW264.7 cells are a good model with which to assess the effect of Res on LPS-induced inflammation . Levels of IL-6, TNF- $\alpha$, and NO in RAW264.7 cells exposed to LPS+Res decreased significantly with Res dose. These results show that Res can inhibit release of IL-6, TNF- $\alpha$, and NO induced by LPS, and that Res antagonizes the inflammatory effects of LPS.

Qureshi et al. reported that Res inhibited the activation of genes of pro-inflammatory cytokines and iNOS when RAW264.7 cells were exposed to LPS, resulting in a reduction of TNF- $\alpha$, IL-1 $\beta$, IL-6, and NO induced by LPS [21]. Thus, Res may be an effective antiinflammatory agent. 
Fig. 6. (A) The expression levels of TLR4 protein in RAW264.7 cells exposed to Res for $1 \mathrm{~h}$ then exposed to LPS for $24 \mathrm{~h}$. (B) The expression levels of TLR4 RNA in RAW264.7 cells exposed to Res for $1 \mathrm{~h}$ then exposed to LPS for 24 h. RAW264.7 cells were divided into four groups: control group, Res (60uM) group, LPS $(0.25 \mathrm{ug} / \mathrm{ml}$ for $24 \mathrm{~h})$ group, and LPS + Res (0.25ug/ $\mathrm{ml}+60 \mathrm{uM}$ ) group. The results of three independent experiments are expressed as the mean \pm SD. a: as compared with other 3 groups, $\mathrm{p}<0.01$.

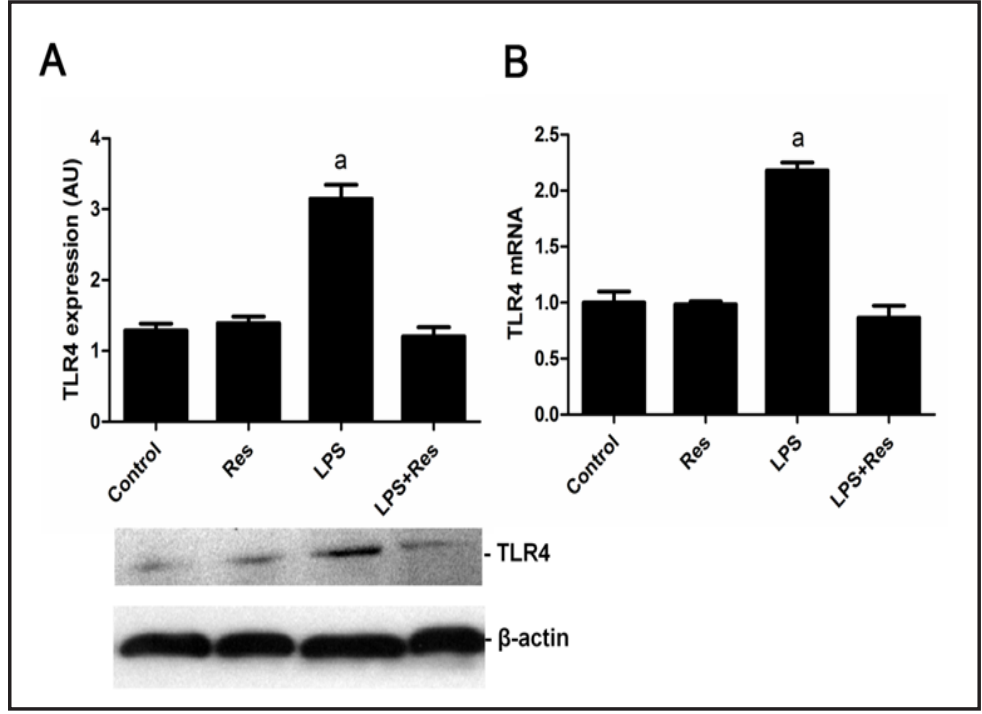

HMGB expression is down-regulated by Res in cells exposed to LPS

High mobility group box 1 (HMGB1) protein was originally described as an intracellular transcription factor, and was recently identified as a late mediator of systemic inflammation. HMGB1 is released from endotoxin-stimulated macrophages after the release of the early cytokines (e.g., TNF, IL-1 $\beta$, IL-6 and IL-8). Cytokine activities of HMGB1 include activation of macrophages and pituicytes to release TNF and IL-1 $\beta$, stimulation of neutrophil and smooth muscle cell chemotaxis, and induction of epithelial cell permeability $[11,15]$. In the present study, not only TNF, IL-6, and NO but also HMGB1 expression was significantly enhanced in cells exposed to LPS. HMGB1 was released from endotoxin (LPS)-stimulated macrophages and the macrophages activated by HMGB1 can release the cytokines (TNF and IL-6).

Recently, some authors pointed out that HMGB1 may be a therapeutic target for sterile inflammation and infection. There are two major pathways of HMGB1 release during invasion or injury: active release and passive release. These are differentiated on the basis of molecular mechanisms, release kinetics, and downstream signaling responses. Passive release, initiated by damage to cellular integrity, is very rapid. Active secretion of HMGB1 is initiated by signal transduction through plasma membrane receptor interaction with extracellular products, when monocytes, macrophages, and other immunologically competent cells are exposed to microbe associated molecular patterns (MAMPs), PAMPs, and endogenously derived inflammatory mediators, including TNF, IL-1 and IFN- $\gamma$ [11]. In our investigation, the secretion of HMGB1 in cells exposed to LPS is presumably active, because Res could reduce not only HMGB1 expression but also the levels of TNF, IL-6, and NO in cells exposed to LPS. Moreover, the expression levels of HMGB1 in RAW264.7 cells exposed to LPS+Res decreased significantly with Res exposure time. It was presumed that Res could selectively target HMGB1 and significantly inhibit the inflammation response in the cellular model exposed to LPS; HMGB1 may be a therapeutic target for Res anti-inflammation effects.

\section{Influence of Res on the HMGB1 signaling pathway}

As stated above, HMGB1 is a DNA-binding protein that possesses cytokine-like, proinflammatory properties. Although HMGB1 interacts with multiple pattern recognition receptors (PRRs), many of its effects in injury models occur through an interaction with TLR4 [34]. The TLRs are a major family of PRRs that reside in cell membranes, both at the cell surface and in endosomes, and that recognize and respond to a variety of bacterial products, PAMPs [35]. TLR4, as a member of the TLR family, also recognizes multiple endogenous damage-associated molecular patterns (DAMPs) such as HMGB1, heat shock proteins (HSPs), etc., which are released after cellular stress or injury and can drive sterile 
inflammatory responses [36-39]. TLR4 activation by bacterial LPS involves the formation of a signaling complex, and HMGB1 displays TLR4-dependent activity [34]. The results of our study showed significant increases of HMGB1 and TLR4 (mRNA and protein) expression in cells exposed to LPS, indicating that LPS activates TLR4 and HMGB1. In contrast, Res could inhibit the expression of HMGB1 and TLR4 and could reduce the levels of TNF, IL-6, and NO in cells exposed to LPS. The results of our investigation suggest that Res can selectively target TLR4 and inhibit the expression of HMGB1, due to TLR4-dependent activity of HMGB1; and, finally, it can significantly attenuate damage in cells exposed to LPS.

\section{Conclusion}

Res can reduce the levels of IL-6, TNF- $\alpha$ and NO in cells exposed to LPS. Res antagonizes the inflammatory effects of LPS. Res can decrease HMGB1 expression in cells exposed to LPS. Res can selectively target HMGB1 for anti-inflammation effects. HMGB1 and TLR4 expression levels in cells exposed to LPS+Res were significantly lower than in cells exposed to LPS. Res could selectively target TLR4 and then inhibit the expression of HMGB1, owing to TLR4-dependent activity of HMGB1.

\section{Abbreviations}

LPS (Lipopolysaccharide); TLR4 (Toll-like receptor 4); IL-6 (interleukin-6); NO (nitric oxide); iNOS (inducible NO synthase); TNF- $\alpha$ (Tumour Necrosis Factor- $\alpha$ ); HMGB1 (High mobility group box 1); Res (Resveratrol); RAW264.7 cells (murine macrophagelike RAW264.7 cells); PCNA (proliferating cell nuclear Ag); 7-AAD (7-amino-actinomycin D); MAMPs (microbe associated molecular patterns); PAMPs (pathogen-associated molecular patterns); PRRs (pattern recognition receptors); DAMPs (damage-associated molecular patterns); HSPs (heat shock proteins).

\section{Disclosure Statement}

The authors declare no conflict of interest.

\section{Acknowledgments}

We thank Tingting $\mathrm{Wu}$ and Hangping Yao for help of experiment skills. This work was supported by the State S\&T Projects of 12th Five Year (2012ZX10002007). This work was also supported by the National Natural Science Foundation of China (81272679).

\section{References}

1 Leu TH, Charoenfuprasert S, Yen CK, Fan CW, Maa MC: Lipopolysaccharide-induced c-Src expression plays a role in nitric oxide and TNFalpha secretion in macrophages. Mol Immunol 2006;43:308-316.

2 Rui Y, Liu X, Li N, Jiang Y, Chen G, Cao X, Wang J: PECAM-1 ligation negatively regulates TLR4 signaling in macrophages. J Immunol 2007;179:7344-7351.

-3 Shen T, Yang WS, Yi YS, Sung GH, Rhee MH, Poo H, Kim MY, Kim KW, Kim JH, Cho JY: AP-1/IRF-3 Targeted Anti-Inflammatory Activity of Andrographolide Isolated from Andrographis paniculata. Evid Based Complement Alternat Med 2013;210736. 
Yang et al.: Res Reduces the Expression of HMGB1 and TLR4 Induced by LPS

4 Lee YG, Lee WM, Kim JY, Lee JY, Lee IK, Yun BS, Rhee MH, Cho JY: Src kinase-targeted anti-inflammatory activity of davallialactone from Inonotus xeranticus in lipopolysaccharide-activated RAW264.7 cells. Br J Pharmacol 2008; 154:852-863.

-5 Yayeh T, Jung KH, Jeong HY, Park JH, Song YB, Kwak YS, Kang HS, Cho JY, Oh JW, Kim SK, Rhee MH: Korean Red Ginseng Saponin Fraction Downregulates Proinflammatory Mediators in LPS Stimulated RAW264.7 Cells and Protects Mice against Endotoxic Shock. J Ginseng Res 2012;36:263-269.

6 Takimoto Y, Qian HY, Yoshigai E, Okumura T, Ikeya Y, Nishizawa M: Gomisin N in the herbal drug gomishi (Schisandra chinensis) suppresses inducible nitric oxide synthase gene via C/EBPbeta and NF-kappaB in rat hepatocytes. Nitric Oxide 2013;28:47-56.

7 Lewis RS, Kolesnik TB, Kuang Z, D‘Cruz AA, Blewitt ME, Masters SL, Low A, Willson T, Norton RS, Nicholson SE: TLR regulation of SPSB1 controls inducible nitric oxide synthase induction. J Immunol 2011;187:37983805.

8 Rendon-Mitchell B, Ochani M, Li J, Han J, Wang H, Yang H, Susarla S, Czura C, Mitchell RA, Chen G, Sama AE, Tracey KJ, Wang H: IFN-gamma induces high mobility group box 1 protein release partly through a TNFdependent mechanism. J Immunol 2003;170:3890-3897.

-9 Chen G, Li J, Ochani M, Rendon-Mitchell B, Qiang X, Susarla S, Ulloa L, Yang H, Fan S, Goyert SM, Wang P, Tracey KJ, Sama AE, Wang H: Bacterial endotoxin stimulates macrophages to release HMGB1 partly through CD14- and TNF-dependent mechanisms. J Leukoc Biol 2004;76:994-1001.

10 Lin T, Sammy F, Yang H, Thundivalappil S, Hellman J, Tracey KJ, Warren HS: Identification of hemopexin as an anti-inflammatory factor that inhibits synergy of hemoglobin with HMGB1 in sterile and infectious inflammation. J Immunol 2012;189: 017-2022.

11 Andersson U, Tracey KJ: HMGB1 is a therapeutic target for sterile inflammation and Infection. Annu Rev Immunol 2011;29:139-162.

-12 Yang H, Hreggvidsdottir HS, Palmblad K, Wang H, Ochani M, Li J, Lu B, Chavan S, Rosas-Ballina M, Al-Abed Y, Akira S, Bierhaus A, Erlandsson-Harris H, Andersson U, Tracey KJ: A critical cysteine is required for HMGB1 binding to Toll-like receptor 4 and activation of macrophage cytokine release. Proc Natl Acad Sci USA 2010;107:11942-11947.

13 Hu HC, Wang TY, Chen YC, Wang CC, Lin MC: RNA interference inhibits high mobility group box 1 by lipopolysaccharide-activated murine macrophage RAW 264.7 secretion. J Surg Res 2011;168:e181-187.

14 Zhu S, Li W, Li J, Sama AE, Wang H: Caging a Beast in the Inflammation Arena: Use of Chinese Medicinal Herbs to Inhibit a Late Mediator of Lethal Sepsis, HMGB1. Int J Clin Exp Med 2008;1:64-75.

-15 Yang H, Ochani M, Li J, Qiang X, Tanovic M, Harris HE, Susarla SM, Ulloa L, Wang H, DiRaimo R, Czura CJ, Wang H, Roth J, Warren HS, Fink MP, Fenton MJ, Andersson U, Tracey KJ: Reversing established sepsis with antagonists of endogenous high-mobility group box 1. Proc Natl Acad Sci USA 2004;101:296-301.

16 Li W, Li J, Ashok M, Wu R, Chen D, Yang L, Yang H, Tracey KJ, Wang P, Sama AE, Wang H: A cardiovascular drug rescues mice from lethal sepsis by selectively attenuating a late-acting proinflammatory mediator, high mobility group box 1. J Immunol 2007;178:3856-3864.

17 Li W, Ashok M, Li J, Yang H, Sama AE, Wang H: A major ingredient of green tea rescues mice from lethal sepsis partly by inhibiting HMGB1. PLoS One 2007;2:e1153.

18 Youn HS, Lee JY, Fitzgerald KA, Young HA, Akira S, Hwang DH: Specific inhibition of MyD88-independent signaling pathways of TLR3 and TLR4 by resveratrol: molecular targets are TBK1 and RIP1 in TRIF complex. J Immunol 2005;175:3339-3346.

19 Jang M, Cai L, Udeani GO, Slowing KV, Thomas CF, Beecher CW, Fong HH, Farnsworth NR, Kinghorn AD, Mehta RG, Moon RC, Pezzuto JM: Cancer chemopreventive activity of resveratrol, a natural product derived from grapes. Science 1997;275:218-220.

20 Pervaiz S: Resveratrol: from grapevines to mammalian biology. FASEB J 2003;17: 975-1985.

21 Qureshi AA, Guan XQ Reis JC, Papasian CJ, Jabre S, Morrison DC, Qureshi N: Inhibition of nitric oxide and inflammatory cytokines in LPS-stimulated murine macrophages by resveratrol, a potent proteasome inhibitor. Lipids Health Dis 2012;11:76.

22 Yang Q Liu Y, Shi Y, Zheng M, He J, Chen Z: The role of intracellular high-mobility group box 1 in the early activation of Kupffer cells and the development of Con A-induced acute liver failure. Immunobiology 2013;218:1284-1292.

23 Zhu F, Ding H, Zhu B: Transcriptional profiling of Drosophila S2 cells in early response to Drosophila C virus. Virol J 2013;10:210. 
Yang et al.: Res Reduces the Expression of HMGB1 and TLR4 Induced by LPS

-24 Simoes AE, Pereira DM, Amaral JD, Nunes AF, Gomes SE, Rodrigues PM, Lo AC, D‘Hooge R, Steer CJ, Thibodeau SN, Borralho PM, Rodrigues CM: Efficient recovery of proteins from multiple source samples after TRIzol((R)) or TRIzol((R))LS RNA extraction and long-term storage. BMC Genomics 2013;14:181.

25 Marcant A, Denys A, Melchior A, Martinez P, Deligny A, Carpentier M, Allain F: Cyclophilin B attenuates the expression of TNF-alpha in lipopolysaccharide-stimulated macrophages through the induction of B cell lymphoma-3. J Immunol 2012;189:2023-2032.

26 Wang H, Bloom O, Zhang M, Vishnubhakat JM, Ombrellino M, Che J, Frazier A, Yang H, Ivanova S, Borovikova L, Manogue KR, Faist E, Abraham E, Andersson J, Andersson U, Molina PE, Abumrad NN, Sama A, Tracey KJ: HMG-1 as a late mediator of endotoxin lethality in mice. Science 1999;285:248-251.

27 Tang D, Shi Y, Kang R, Li T, Xiao W, Wang H, Xiao X: Hydrogen peroxide stimulates macrophages and monocytes to actively release HMGB1. J Leukoc Biol 2007;81:741-747.

-28 Liu WX, Zhu HH, Wu W, He JL, Chen Z: Inhibition effect produced by dominant negative mutant fusion protein PreS2-TLM-ScFv-HBcDN on HBV replication in vitro. J Viral Hepat 2012;19:295-300.

29 Min HJ, Ko EA, Wu J, Kim ES, Kwon MK, Kwak MS, Choi JE, Lee JE, Shin JS: Chaperone-like activity of highmobility group box 1 protein and its role in reducing the formation of polyglutamine aggregates. J Immunol 2013;190:797-1806.

- 30 Xu Q, Si LY: Resveratrol role in cardiovascular and metabolic health and potential mechanisms of action.. Nutr Res 2012;32:648-658.

-31 Svajger U, Jeras M: Anti-inflammatory effects of resveratrol and its potential use in therapy of immunemediated diseases. Int Rev Immunol 2012;31:202-222.

-32 Rossol M, Heine H, Meusch U, Quandt D, Klein C, Sweet MJ, Hauschildt S: LPS-induced cytokine production in human monocytes and macrophages. Crit Rev Immunol 2011;31:379-446.

-33 Miller AM, Horiguchi N, Jeong WI, Radaeva S, Gao B: Molecular mechanisms of alcoholic liver disease: innate immunity and cytokines. Alcohol Clin Exp Res 2011;35:787-793.

-34 Kim S, Kim SY, Pribis JP, Lotze M, Mollen KP, Shapiro R, Loughran P, Scott MJ, Billiar TR: Signaling of high mobility group box 1 (HMGB1) through toll-like receptor 4 in macrophages requires CD14. Mol Med 2013;19:88-98.

-35 Ve T, Gay NJ, Mansell A, Kobe B, Kellie S: Adaptors in toll-like receptor signaling and their potential as therapeutic targets. Curr Drug Targets 2012;13:1360-1374.

-36 Bianchi ME: DAMPs, PAMPs and alarmins: all we need to know about danger. J Leukoc Biol 2007;81:1-5.

37 Evankovich J, Billiar T, Tsung A: Toll-like receptors in hepatic ischemia/reperfusion and Transplantation. Gastroenterol Res Pract 2010;537263.

-38 Langefeld T, Mohamed W, Ghai R, Chakraborty T: Toll-like receptors and NOD-like receptors:domain architecture and cellular signalling. Adv Exp Med Biol 2009;653:48-57.

-39 Piccinini AM, Midwood KS: DAMPening inflammation by modulating TLR signalling. Mediators Inflamm 2010;2010:672395. 